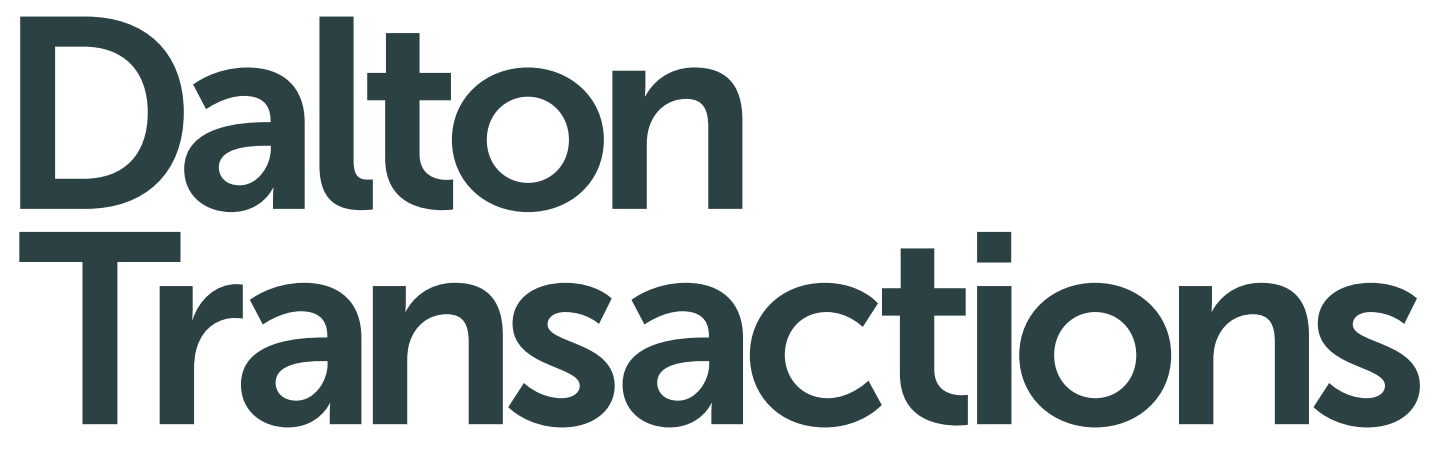

An international journal of inorganic chemistry
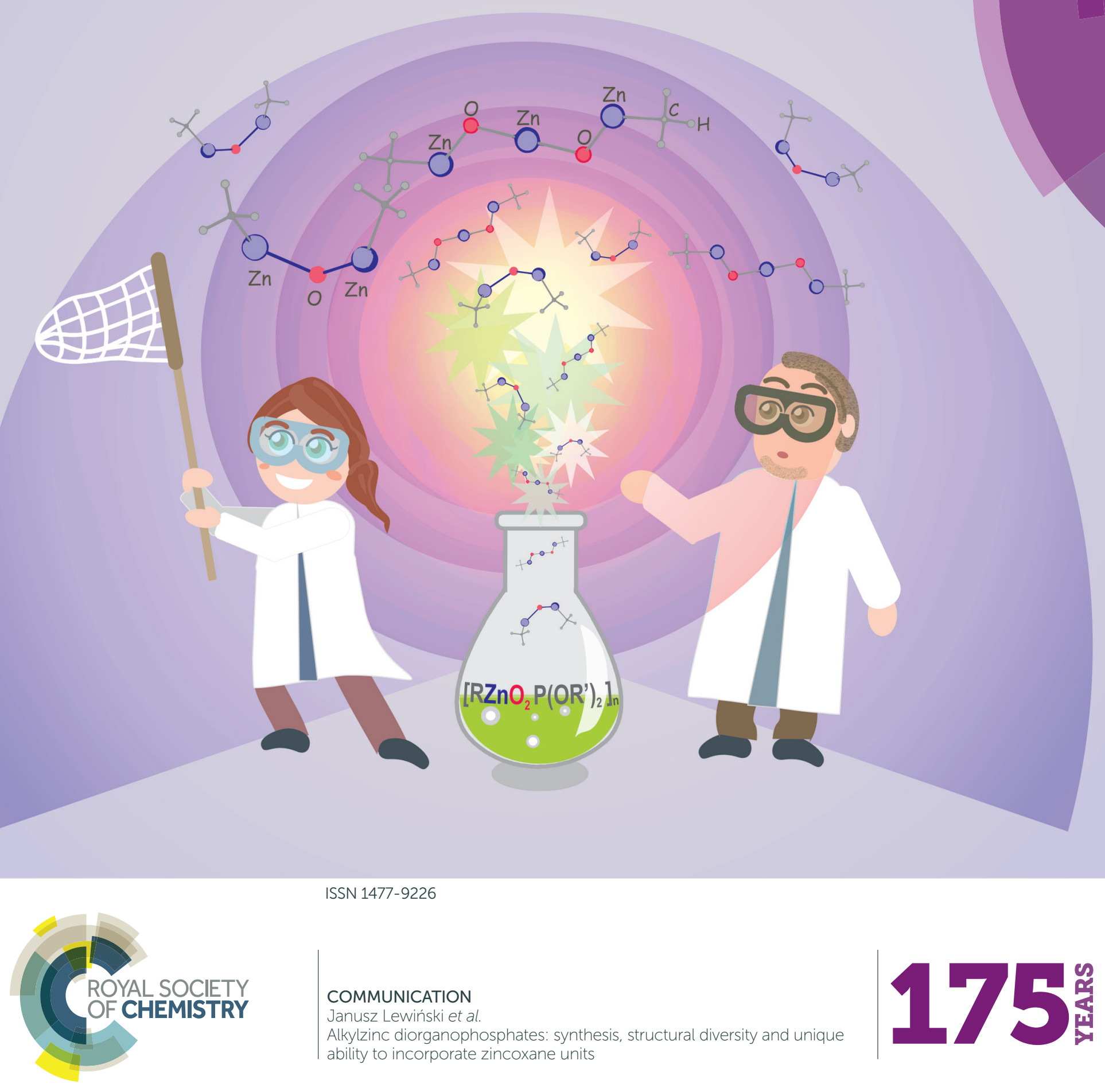


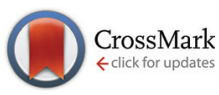

Cite this: Dalton Trans., 2016, 45 18813

Received 24th August 2016,

Accepted 18th October 2016

DOI: $10.1039 / c 6 d t 03324 e$

\section{Alkylzinc diorganophosphates: synthesis, structural diversity and unique ability to incorporate zincoxane units $\uparrow$}

\author{
Małgorzata Wolska-Pietkiewicz,,$^{a}$ Adam Świerkosz, $\$^{\mathrm{a}}$ Iwona Justyniak, \\ Agnieszka Grala, ${ }^{\mathrm{b}}$ Kamil Sokołowski ${ }^{\mathrm{b}}$ and Janusz Lewiński ${ }^{\star \mathrm{a}, \mathrm{b}}$
}

www.rsc.org/dalton

Equimolar reactions between $\mathrm{ZntBu}_{2}$ and diphenyl phosphate (dpphe-H) or dimethyl phosphate (dmphe-H) result in the formation of $\left[t \mathrm{BuZn}\left(\mathrm{O}_{2} \mathrm{P}\left(\mathrm{OR}^{\prime}\right)_{2}\right)\right]$-type compounds which crystallize as tetranuclear aggregates, $[t \mathrm{BuZn}(\text { dpphe })]_{4}\left(1_{4}\right)$ or $[t \mathrm{BuZn}(d m p h e)]_{4}$ $\left(2_{4}\right)$, with the phosphate ligands spanning 4-coordinate $\mathrm{Zn}$ centers. The utility of $\mathrm{ZnMe}_{2}$ instead of $\mathrm{ZntBu_{2 }}$ dramatically changes the reaction outcome and leads to $\left[\mathrm{MeZn}\left(\mathrm{O}_{2} \mathrm{P}\left(\mathrm{OR}^{\prime}\right)_{2}\right)\right]$-type moieties incorporating zincoxane units, i.e., pentanuclear $[\{\mathrm{MeZn}$ (dpphe) $\left.\}_{3}\left(\mathrm{Me}_{2} \mathrm{Zn}_{2} \mathrm{O}\right)(\mathrm{THF})_{2}\right] \quad$ (3) and nonanuclear [\{MeZn (dmphe) $\left.\}_{6}\left(\mathrm{Me}_{2} \mathrm{Zn}_{3} \mathrm{O}_{2}\right)\right]$ (4) aggregates. The resulting compounds were characterized by ${ }^{1} \mathrm{H}$ and ${ }^{31} \mathrm{P}$ NMR spectroscopy and singlecrystal X-ray diffraction analysis.

Since the first zinc-based phosphate molecular sieves related to the structure of zeolitic aluminosilicates were published in $1991,{ }^{1}$ there has been rapid and continuous growth in the area of the synthesis and the application of metal complexes and the corresponding functional materials supported by a vast array of phosphorus oxyacids and their organic derivatives. ${ }^{2}$ Such materials revealing versatile structures from zero-dimensional molecular complexes to three-dimensional frameworks have been used mainly in catalysis, ion-exchange and materials chemistry including rational design of porous materials or gas storage. ${ }^{2}$ Moreover, molecular metal complexes of phosphorus oxyacids have also received considerable interest as potential secondary building blocks of extended structures of various dimensionalities and architectures. ${ }^{2-4}$ Within this realm, zinc phosphates occupy a prominent position. However, both the number of structurally well-characterized molecular zinc phosphates as well as the knowledge on their transformation modes from low- to high-dimensional structures remain rela-

\footnotetext{
${ }^{a}$ Faculty of Chemistry, Warsaw University of Technology, Noakowskiego 3, 00-664 Warsaw, Poland

${ }^{b}$ Institute of Physical Chemistry, Polish Academy of Sciences, Kasprzaka 44/52, 01-224 Warsaw, Poland

$\dagger$ Electronic supplementary information (ESI) available: All experimental details and characterization data. CCDC 1499962-1499965. For ESI and crystallographic data in CIF or other electronic format see DOI: 10.1039/c6dt03324e

$\$$ These authors contributed equally to the manuscript.
}

tively limited. This obstacle mainly arises from the fact that zinc and other metal phosphates are commonly synthesized by hydrothermal synthetic methods. ${ }^{5}$ In order to isolate molecular complexes, addition of ancillary ligands is usually required and is in line with this strategy, for example, a number of novel inorganic zinc-based molecular complexes incorporating organophosphate ligands were isolated and structurally characterized. ${ }^{6}$ An alternative to this inorganic route may potentially be an organometallic approach. However, the corresponding organozinc compounds still represent a highly unexplored field. Strikingly, only a few organometallic zinc compounds bearing a characteristic structural motif [RZn $\left.\left(\mathrm{O}_{x} \mathrm{PR}_{y}^{\prime}\right)\right]$ (wherein $\mathrm{R}$ and $\mathrm{R}^{\prime}=$ alkyl or aryl, $x=2-4$, $y=1-2$ ) have been crystallographically characterized to date. For example, in the course of extensive investigations on metal phosphonates, ${ }^{2 a, 7}$ Roesky and co-workers described the reaction of tert-butylphosphonic acid with zinc dialkyls in different molar ratios, which resulted in the formation of structurally varied organozinc phosphonates: tetranuclear $\left[\left\{(\mathrm{ZnMe})_{4}(\mathrm{THF})_{2}\right\}\left\{\mathrm{BuPO}_{3}\right\}_{2}\right]$ and hexanuclear $\left[\left\{(\mathrm{ZnEt})_{3}\right.\right.$ $\left.\left.(\mathrm{Zn}(\mathrm{THF}))_{3}\right\}\left\{t \mathrm{BuPO}_{3}\right\}_{4}\left\{\mu_{3}-\mathrm{OEt}\right\}\right]$ complexes, and a dodecanuclear aggregate $\left.\left[\left\{\mathrm{Zn}_{2}(\mathrm{THF})_{2}(\mathrm{ZnEt})_{6} \mathrm{Zn}_{4}\left(\mu_{4}-\mathrm{O}\right)\right\}\left(t \mathrm{BuPO}_{3}\right)_{8}\right\}\right]$ with a $\left[\mathrm{Zn}_{4}\left(\mu_{4}-\mathrm{O}\right)\right]^{6+}$ core, respectively. ${ }^{8}$ To the best of our knowledge, heretofore only one structurally characterized organozinc phosphate, namely a dimeric iodomethylzinc phosphate $\left[\mathrm{ICH}_{2} \mathrm{Zn}(\text { dpphe })\right]_{2}$ (where, dpphe - diphenyl phosphate monoanion), was reported. This compound was derived from the reaction of dpphe- $\mathrm{H}$ with 1 equiv. of $\mathrm{ZnEt}_{2}$ along with the consecutive addition of 1 equiv. of $\mathrm{CH}_{2} \mathrm{I}_{2}$ and then was used as an efficient reagent for the cyclopropanation of alkenes. ${ }^{9}$

As part of our ongoing interest in both new molecular organozinc building blocks for inorganic-organic functional materials ${ }^{10}$ and well-defined precursors of organic ligandcoated $\mathrm{ZnO}$ nanocrystals, ${ }^{11}$ we turn our attention to molecular complexes incorporating organophosphate ligands. Herein we report the preliminary experiments involving the reactions of $\mathrm{ZnR}_{2}(\mathrm{R}=t \mathrm{Bu}$ and $\mathrm{Me})$ with organophosphate diesters. To gain insights into the factors determining reaction outcomes and structures of the resulting alkylzinc phosphates, except various 
a)

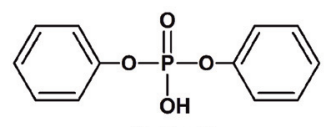

b)

dpphe-H

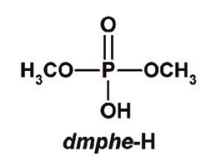

substituents at zinc, two different organophosphates were selected as proligands, i.e., diphenyl phosphate (dpphe-H) and dimethyl phosphate (dmphe-H) (Scheme 1a).

All the reactions between the selected phosphate proligands and $\mathrm{ZnR}_{2}(\mathrm{R}=t \mathrm{Bu}, \mathrm{Me})$ were carried out according to Scheme $1 \mathrm{~b}$. An equimolar reaction of $\mathrm{Zn} t \mathrm{Bu}_{2}$ with dpphe- $\mathrm{H}$ or dmphe-H in toluene at $-78{ }^{\circ} \mathrm{C}$ lead to the formation of $[t \mathrm{BuZn}$ $\left(\mathrm{O}_{2} \mathrm{P}\left(\mathrm{OR}^{\prime}\right)_{2}\right)$-type compounds which crystallize as tetranuclear aggregates $[t \operatorname{BuZn}(d p p h e)]_{4}\left(\mathbf{1}_{\mathbf{4}}\right)$, and $[t \operatorname{BuZn}(d m p h e)]_{4}\left(\mathbf{2}_{\mathbf{4}}\right)$ (for details, see the ESI $\dagger$ ). In both cases colourless rectangular crystals suitable for X-ray diffraction analyses were almost quantitatively isolated from the postreaction mixtures. Conversely, the utility of $\mathrm{ZnMe}_{2}$ instead of $\mathrm{Zn} t \mathrm{Bu}_{2}$ dramatically changes the reaction outcome and afforded two methylzinc(oxo)phosphate complexes, which exhibited solvent-dependent aggregation degrees. The reaction between $\mathrm{ZnMe}_{2}$ and 1 equiv. of dpphe- $\mathrm{H}$ in a toluene solution leads to an insoluble product. Dissolution of the resulting solid in THF followed by crystallization at low temperature afforded a novel organozinc oxo cluster supported by the diphenyl phosphate ligands with the formula $\left[\{\mathrm{MeZn}(\text { dpphe })\}_{3}\left(\mathrm{Me}_{2} \mathrm{Zn}_{2} \mathrm{O}\right)(\mathrm{THF})_{2}\right](3)$. However, in a similar reaction system involving dmphe- $\mathrm{H}$, a nonanuclear cluster $\left[\{\mathrm{MeZn}(\text { dmphe })\}_{6}\left(\mathrm{Me}_{2} \mathrm{Zn}_{3} \mathrm{O}_{2}\right)\right]$ (4) was isolated in high yield. The observed formation of zinc oxo species is an intriguing issue. We note that the reported reactions were performed using the standard Schlenk technique with the same batches of solvents. Because of the observed relatively high reaction yields, the presence of the oxo-zinc species cannot be attributed to adventitious moisture or traces of dioxygen. In our opinion, the origin of zincoxane units may likely be associated with a condensation of organophosphate molecules mediated by $\mathrm{ZnMe}_{2}$ and the subsequent formation of an organopyrophosphate moiety related to the processes observed in biochemistry ( $c f$. ATP biosynthesis); the presence of tetraphenyl pyrophosphate and products of its decomposition were confirmed by EI-MS in the postreaction mixtures (for details, see the ESI $\dagger$ ).

The resulting compounds $\mathbf{1 - 4}$ were fully characterized using spectroscopic techniques and single crystal X-ray diffraction studies. The IR spectra are devoid of any characteristic absorption in the region $2700-2500 \mathrm{~cm}^{-1}$ and $\sim 3600 \mathrm{~cm}^{-1}$, indicating a complete reaction of all $\mathrm{P}-\mathrm{O}-\mathrm{H}$ groups with $\mathrm{ZnR}_{2}$. Moreover, for 1-4 the characteristic vibrational $\mathrm{P}-\mathrm{O}-\mathrm{Zn}$ stretches appear as bands of strong intensities at $1054 \mathrm{~cm}^{-1}$, $1032 \mathrm{~cm}^{-1}, 1097 \mathrm{~cm}^{-1}$ and $1025 \mathrm{~cm}^{-1}$, respectively. All ${ }^{1} \mathrm{H}$ NMR spectra are consistent with the structures found in the solid state. The ${ }^{1} \mathrm{H}$ NMR spectra of 1-4 contain well-resolved signals characteristic for the alkyl groups bonded to zinc centres and the sets of signals for the corresponding phosphate ligands (Fig. S1a-S4a $\dagger$ ). The ${ }^{31} \mathrm{P}$ NMR spectra of 1, 2 and 3 show a single resonance at $-16.79 \mathrm{ppm},-1.35 \mathrm{ppm}$ and -9.67 ppm, respectively, (Fig. S1b-S3b†). However, the ${ }^{31} \mathrm{P}$ NMR of 4 comprises two signals at $1.37 \mathrm{ppm}$ and $5.91 \mathrm{ppm}$ which is consistent with the presence of two nonequivalent dmphe ligands in the solid state structure (Fig. $\mathrm{S} 4 \mathrm{~b} \dagger$ ).

Compounds $\mathbf{1}_{\mathbf{4}}$ and $\mathbf{2}_{\mathbf{4}}$ crystallize in the triclinic $P \overline{\mathbf{1}}$ space group as tetrameric structures with four-coordinate zinc centres. The molecular structures of $\mathbf{1}$ and $\mathbf{2}$ are shown in Fig. 1 and S6 (see the ESI†), respectively. In both cases the

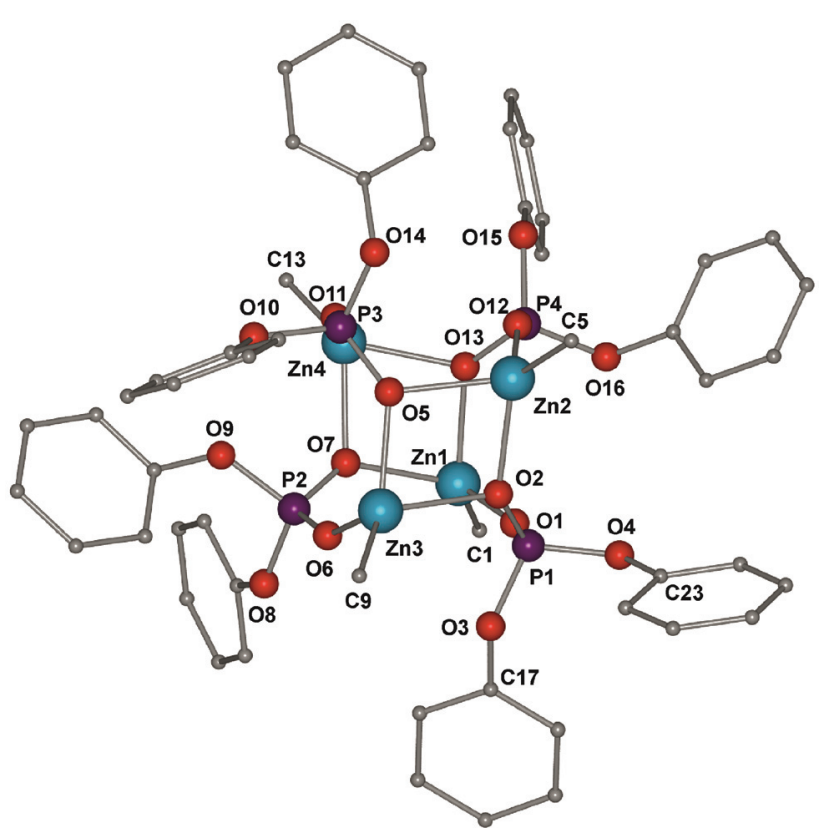

Fig. 1 Molecular structure of $1_{4}$; hydrogen atoms and methyl groups of the tert-butyl substituents are omitted for clarity. 
association of four $\left[t \mathrm{BuZn}\left(\mathrm{O}_{2} \mathrm{P}\left(\mathrm{OR}^{\prime}\right)_{2}\right)\right]$ moieties results in a quasi-cube-shaped central core, which is made up of two 8-membered heterocycles $\mathrm{Zn}_{2} \mathrm{P}_{2} \mathrm{O}_{4}$ joined by two 4-membered $\mathrm{Zn}_{2}\left(\mu_{2}-\mathrm{O}\right)_{2}$ rings. Each of these eight-membered rings adopts a pseudo-boat conformation. The periphery of the central $\mathrm{Zn}_{4} \mathrm{P}_{4} \mathrm{O}_{8}$ polyhedron is surrounded by hydrophobic tert-butyl and $-\mathrm{P}\left(\mathrm{OR}^{\prime}\right)_{2}$ groups (where $\mathrm{R}^{\prime}=-\mathrm{Ph}\left(\mathbf{1}_{\mathbf{4}}\right),-\mathrm{CH}_{3}\left(\mathbf{2}_{\mathbf{4}}\right)$ ), which is consistent with the high solubility of $\mathbf{1}_{\mathbf{4}}$ and $\mathbf{2}_{\mathbf{4}}$ in common organic solvents. The bridging phosphate groups between three zinc centres display a $\mu_{3}-\mu_{2}: \eta^{1}$ coordination mode. The $\mathrm{Zn}-\mathrm{C}$ and $\mathrm{Zn}-\mathrm{O}$ bonds fall within a narrow range of

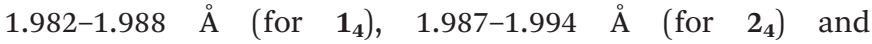
1.972-2.151 $\mathrm{A}\left(\mathbf{1}_{4}\right), 1.977-1.216 \AA\left(\mathbf{2}_{4}\right)$, respectively.

The methylzinc(oxo)phosphate 3 crystallizes in the triclinic space group as a pentanuclear complex. The molecular structure of 3 contains a $\mathrm{Zn}_{4} \mathrm{O}_{7} \mathrm{P}_{3}$ core stabilized by the three phosphate ligands (Fig. 2). Each dpphe ligand bridges three zinc centers and adopts a $\mu_{3}-\mu_{2}: \eta^{1}$ coordination mode. A striking feature of this structure is the presence of a zincoxane unit. Hence, the revealed very unusual oxo-zinc structure of 3 can be formally described as a zincoxane $\left(\mathrm{Me}_{2} \mathrm{Zn}_{2} \mathrm{O}\right)$ moiety entrapped by three $[\operatorname{MeZn}($ dpphe $)]$ molecules. As a result, the molecular structure of 3 contains a total of two eight-membered $\mathrm{Zn}_{2} \mathrm{P}_{2} \mathrm{O}_{4}$ rings and three four-membered $\mathrm{Zn}_{2} \mathrm{O}_{2}$ rings. Moreover, one MeZn subunit of the zincoxane is anchored in the central core and the second, terminal MeZn subunit is stabilized by two $\eta^{1}$-THF molecules. All the zinc centres are tetra-coordinate and possess a near tetrahedral geometry. Due to a poor quality of crystals of $\mathbf{3}$ for single-crystal X-ray diffraction, it was not possible to obtain a fully satisfactory refinement of the molecular structure, and this precludes also a detailed discussion of the geometrical parameters.

Compound 4 crystallizes in the centrosymmetric monoclinic space group and its molecular structure is shown in Fig. 3. The

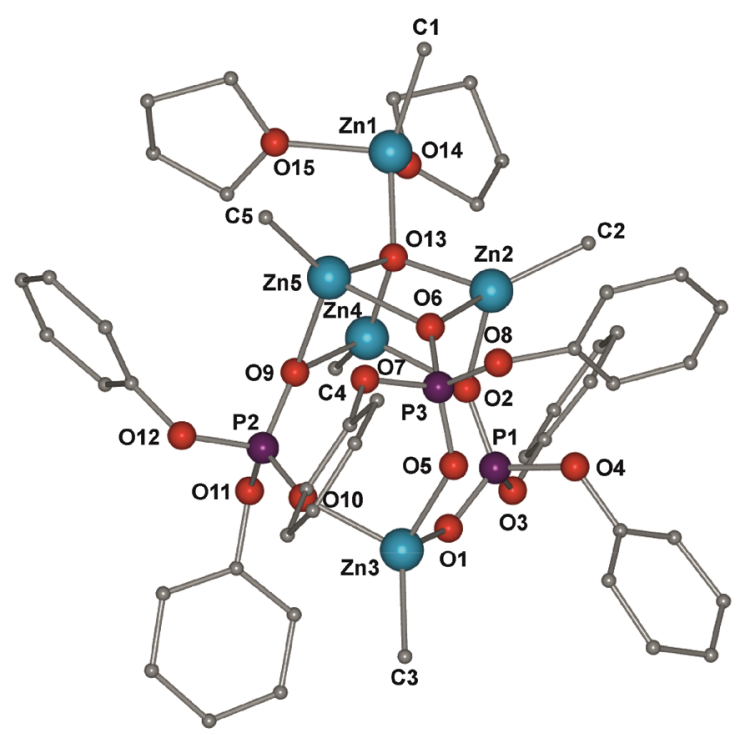

Fig. 2 Molecular structure of 3; hydrogen atoms are omitted for clarity.

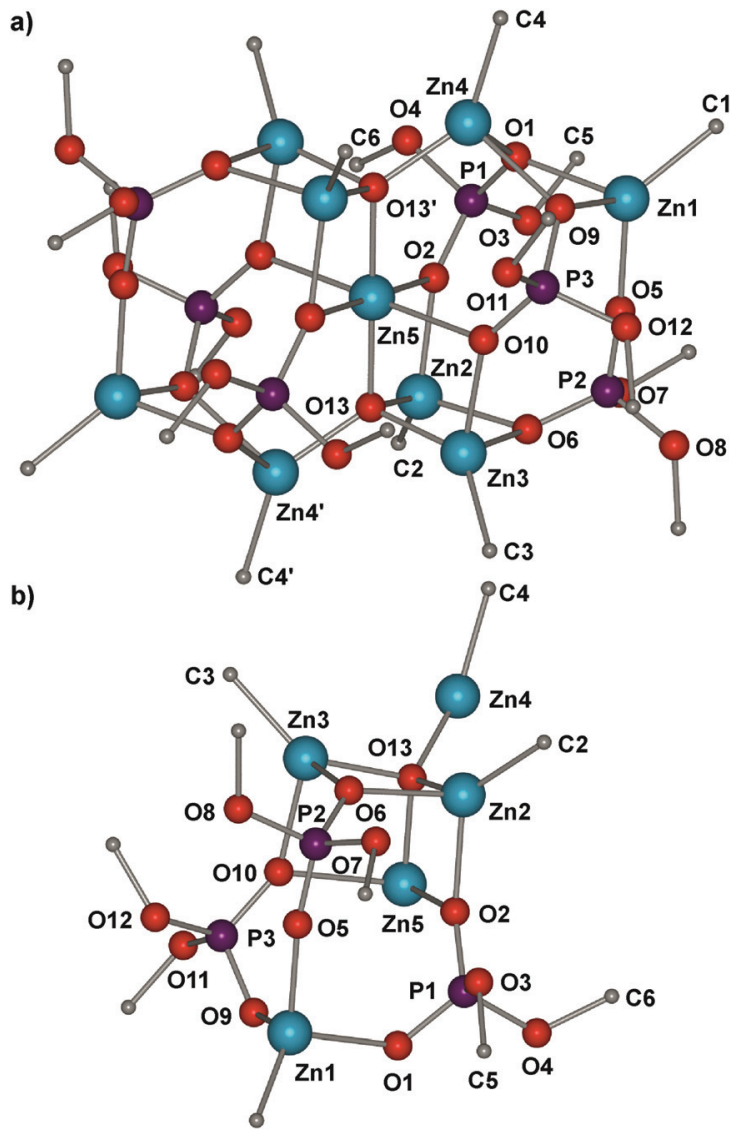

Fig. 3 (a) Molecular structure of 4 and (b) its asymmetric unit; hydrogen atoms are omitted for clarity.

oxo-zinc structure of $\mathbf{4}$ can be formally described as two trinuclear $[\operatorname{MeZn}(d p p h e)]_{3}$ subunits with an entrapped trinuclear zincoxane moiety, $\left(\mathrm{Me}_{2} \mathrm{Zn}_{3} \mathrm{O}_{2}\right)$. It results in the formation of the $\mathrm{Zn}_{9} \mathrm{P}_{6} \mathrm{O}_{13}$ cage, which is made up of a combination of two eight-membered $\mathrm{Zn}_{2} \mathrm{P}_{2} \mathrm{O}_{4}$, four six-membered $\mathrm{Zn}_{2} \mathrm{P}_{1} \mathrm{O}_{3}$ and eight four-membered $\mathrm{Zn}_{2} \mathrm{O}_{2}$ rings. Depending on the coordination modes, the six dmphe groups can be classified into two different types and the phosphate monoanionic ligands are in two distinctive $\mu_{4}-\mu_{2}: \mu_{2}$ and $\mu_{3}-\mu_{2}: \eta^{1}$ coordination modes. The $\mathrm{Zn}_{4}\left(\mu_{4}-\mathrm{O}\right)$ bond distances in 4 range from 1.834 to $2.006 \AA$, and the $\mathrm{Zn}-\mathrm{O}_{\text {(phosphate) }}$ distances range from 1.968 to $2.196 \AA$. These values are similar to the average value of those found in the reported zinc oxophosphate tetranuclear cluster $\left[\mathrm{Zn}_{4}\left(\mu_{4}-\mathrm{O}\right)\right.$ $\left.\left\{\mathrm{O}_{2} \mathrm{P}(\mathrm{O} t \mathrm{Bu})_{2}\right\}\right]_{6} \quad(2.00$ and $1.93 \AA$, respectively $) .{ }^{12}$ Moreover, there are no formal $\mathrm{P}-\mathrm{O}$ and $\mathrm{P}=\mathrm{O}$ bonds in 1-2 and 4 , and the average P-O bond lengths: $1.51 \AA$ (for $\mathbf{1}_{4}$ ), 1.50 (for $\mathbf{2}_{4}$ ), $1.50 \AA$ (for 4) are much shorter than a formal P-O bond (1.59-1.60 ̊̊) and considerably longer than a formal $\mathrm{P}=\mathrm{O}$ bond (1.45-1.46 ̊) ${ }^{13}$ It is essential to note that compounds 3 and 4 bear a striking resemblance to each other. Particularly, both methylzinc(oxo)phosphates contain a pentanuclear structural motif with a zincoxane unit incorporated into methylzinc diorganophosphate moieties. 


\section{Conclusions}

In conclusion, we prepared and characterized novel and structurally diverse organozinc complexes stabilized by organophosphate diesters. While the reaction involving bulky $\mathrm{Zn} t \mathrm{Bu}_{2}$ results in the formation of $\left[t \mathrm{BuZn}\left(\mathrm{O}_{2} \mathrm{P}\left(\mathrm{OR}^{\prime}\right)_{2}\right)\right]$-type organozinc compounds, the utility of $\mathrm{ZnMe}_{2}$ dramatically changes the reaction outcome and leads to methylzinc organophosphate complexes incorporating zincoxane units. The resulting structures reproduce the salient bonding features of the phosphate zincoxanes which likely illuminate the structural changes in molecules and intermediate compounds that may exist only briefly during a transformation process of organozinc phosphates into ZnO nanocrystals. Further studies on the chemistry of organozinc complexes supported by a vast array of phosphorus oxyacids and their organic derivatives as well as their transformation into extended inorganic-organic porous materials and ZnO-based nanomaterials are currently in progress.

\section{Acknowledgements}

The authors acknowledge the Foundation for Polish Science Team Program co-financed by the EU "European Regional Development Fund" TEAM/2011-7/8 and the National Science Centre, Grant Maestro DEC-2012/04/A/ST5/00595 for financial support.

\section{Notes and references}

1 T. E. Gier and G. D. Stucky, Nature, 1991, 349, 508.

2 (a) M. G. Walawalkar and H. W. Roesky, Acc. Chem. Res., 1999, 32, 117; (b) R. Murugavel, A. Choudhury, M. G. Walawalkar, R. Pothiraja and C. N. R. Rao, Chem. Rev., 2008, 108, 3549; (c) V. Chandrasekhar, T. Senapati, A. Deya and S. Hossaina, Dalton Trans., 2011, 40, 5394; (d) J. Goura and V. Chandrasekhar, Chem. Rev., 2015, 115, 6854.

3 K. J. Gagnon, H. P. Perry and A. Clearfield, Chem. Rev., 2012, 112, 1034.

4 J. A. Sheikh, H. S. Jena, A. Clearfield and S. Konar, Acc. Chem. Res., 2016, 49, 1093.

5 A. J. Norquist and D. O'Hare, J. Am. Chem. Soc., 2004, 126, 6673.

6 (a) R. Murugavel, S. Kuppuswamy, R. Boomishankar and A. Steiner, Angew. Chem., Int. Ed., 2006, 45, 5536; (b) R. Murugavel, S. Kuppuswamy, N. Gogoi, R. Boomishankar and A. Steiner, Chem. - Eur. J., 2010, 16, 994; (c) A. Kalita, C. Roch-Marchal and R. Murugavel, Dalton Trans., 2013, 42, 9755; (d) A. A. Dar, S. K. Sharma and R. Murugavel, Inorg. Chem., 2015, 54, 4882; (e) A. A. Dar, S. Sen, S. K. Gupta, G. N. Patwari and R. Murugavel, Inorg. Chem., 2015, 54, 9458.

7 For selected examples, see: (a) M. G. Walawalkar, R. Murugavel, A. Voigt, H. W. Roesky and H.-G. Schmidt,
J. Am. Chem. Soc., 1997, 119, 4656; (b) M. G. Walawalkar, R. Murugavel, H. W. Roesky and H.-G. Schmidt, Inorg. Chem., 1997, 36, 4202; (c) M. Ganapati Walawalkar, R. Murugavel, H. W. Roesky and H.-G. Schmidt, Organometallics, 1997, 16, 516; (d) Y. Yang, H.-G. Schmidt, M. Noltemeyer, J. Pinkas and H. W. Roesky, J. Chem. Soc., Dalton Trans., 1996, 3609; (e) G. Anantharaman, M. G. Walawalkar, R. Murugavel, B. Gábor, R. HerbstIrmer, M. Baldus, B. Angerstein and H. W. Roesky, Angew. Chem., Int. Ed., 2003, 42, 4482.

8 (a) Y. Yang, J. Pinkas, M. Noltemeyer, H.-G. Schmidt and H. W. Roesky, Angew. Chem., Int. Ed., 1999, 38, 664; (b) G. Anantharaman, V. Chandrasekhar, M. G. Walawalkar, H. W. Roesky, D. Vidovic, J. Magull and M. Noltemeyer, Dalton Trans., 2004, 1271.

9 M.-C. Lacasse, C. Poulard and A. B. Charette, J. Am. Chem. Soc., 2005, 127, 12440.

10 For selected examples, see: (a) W. Bury, I. Justyniak, D. Prochowicz, Z. Wróbel and J. Lewiński, Chem. Commun., 2012, 48, 7362; (b) K. Sokołowski, W. Bury, I. Justyniak, D. Fairén-Jiménez, K. Sołtys, D. Prochowicz, S. Yang, M. Schröder and J. Lewiński, Angew. Chem., Int. Ed., 2013, 52, 13414; (c) W. Bury, I. Justyniak, D. Prochowicz, A. RolaNoworyta and J. Lewiński, Inorg. Chem., 2012, 51, 7410; (d) D. Prochowicz, K. Sokołowski, I. Justyniak, A. Kornowicz, D. Fairen-Jimenez, T. Friščić and J. Lewiński, Chem. Commun., 2015, 51, 4032; (e) A. Grala, M. WolskaPietkiewicz, A. Wojewódzka, M. Dabergut, I. Justyniak and J. Lewiński, Organometallics, 2015, 34, 4959; (f) K. Sokołowski, W. Bury, A. Tulewicz, A. M. Cieślak, I. Justyniak, D. Kubicki, E. Krajewska, A. Milet, R. Moszyński and J. Lewiński, Chem. - Eur. J., 2015, 21, 5496; (g) Z. Wróbel, I. Justyniak, I. Dranka and J. Lewiński, Dalton Trans., 2016, 45, 7240.

11 (a) A. Grala, M. Wolska-Pietkiewicz, W. Danowski, Z. Wróbel, J. Grzonka and J. Lewiński, Chem. Commun., 2016, 52, 7340; (b) P. Krupiński, A. Kornowicz, K. Sokołowski, A. M. Cieślak and J. Lewiński, Chem. - Eur. J., 2016, 22, 7817; (c) J. Paczesny, M. Wolska-Pietkiewicz, I. Binkiewicz, M. Wadowska, Z. Wróbel, K. Matuła, W. Nogala, J. Lewiński and R. Hołyst, ACS Appl. Mater. Interfaces, 2016, 8, 13532; (d) J. Paczesny, M. WolskaPietkiewicz, I. Binkiewicz, Z. Wróbel, M. Wadowska, K. Matuła, I. Dzięcielewski, D. Pociecha, J. SmalcKoziorowska, J. Lewiński and R. Hołyst, Chem. - Eur. J., 2015, 21, 16941; (e) K. Sokołowski, I. Justyniak, W. Bury, J. Grzonka, Z. Kaszkur, Ł. Mąkolski, M. Dutkiewicz, A. Lewalska, D. Kubicki, K. Wójcik, K. Kurzydłowski and J. Lewiński, Chem. - Eur. J., 2015, 21, 5488; (f) W. Bury, E. Krajewska, M. Dutkiewicz, K. Sokołowski, I. Justyniak, Z. Kaszkur, K. J. Kurzydłowski, T. Płociński and J. Lewiński, Chem. Commun., 2011, 47, 5467.

12 C. G. Lugmair, T. D. Tilley and A. L. Rheingold, Chem. Mater., 1997, 9, 339.

13 D. E. C. Corbridge, The Structural Chemistry of Phosphorus, Elsevier, Amsterdam, 1974. 